\title{
Time and Food for Thought
}

\author{
Fyodor A. Lukyanov
}

DOI: $10.31278 / 1810-6374-2020-18-1-5-8$

What should one do if he is interested in world issues, but international life is basically coming to a standstill, trying to shy away from a pandemic? To us, the answer is obvious: read Russia in Global Affairs and use the intermission to think about what is happening on planet Earth.

Assessments of the events that started this past winter range widely from apocalyptic to daring, and from despair to negation. The paradox is that all are probably right. At any rate, one can find convincing arguments to uphold any view.

The coronavirus effect, like nothing else, has proved that the world system is interconnected, and there is no such thing as solid borders any more. Globalization is all-embracing. It certainly is. The new infection has exposed the vulnerability of all and everyone and boosted tremendously the political and economic trends towards isolation that have lately been gaining momentum anyway. So deglobalization will accelerate. At least, this is quite likely.

Democratic forms of social and political order are poorly adapted to such force majeure circumstances.
Only authoritarian systems capable of taking decisive action and organizing rapid mobilization achieve real results. Let us compare China and Italy, for example. What matters is not the form of government, but the efficiency of government institutions that can make decisions quickly. Norway is a truly democratic state, but it adopted tough measures right away.

Mankind is facing a very big and multifaceted threat, the consequences of which, from economic to biological ones, are impossible to predict. One of the reasons is that none of us has ever seen quarantine of such scale, and analogies are hard to draw. What is happening is just one giant bubble, and the threat has been blown out of any reasonable proportion, if one looks at the real numbers, especially globally. Rampant media reports are whipping up mass hysteria to the extent that by far exceeds the real danger. And this can hardly be denied.

This is how it is going to be from now on. There has never been any single and comprehensive picture of the world before, but in an era of 
omnipotent communication technologies and the ability to quickly create any reality, one can forget about a holistic worldview, as it changes depending on the current needs.

Infinite opportunities are opening up for those who analyze international affairs. Changes and imbalances that have been piling up for decades are now acquiring a new quality, catalyzed by the virus. Further scenarios vary, but the situation probably will not get back to what it was before. The sociopolitical and economic consequences-not of the epidemic, but of a combination of processes-will have to be sorted out for many months and years to come.

For the time being, however, we will stick to the preplanned agenda. Our authors talk about modern political culture in Russia. This topic has become quite relevant lately due to constitutional amendments, which, in turn, are connected with a possible transition of power. The novelties announced by Vladimir Putin have evoked a controversial reaction, and the final design of the future political system is not clear yet. But those who prefer a strong presidency and would probably even want the incumbent head of state to remain in office appeal primarily to the dangerous and unpredictable international situation. Never change horses in midstream, they say. Especially like this one. And, of course, the underlying ideology of the constitutional amendments is conservative and traditionalist to counterbalance the whirling international chaos.

Paul Robertson examines the Russian understanding of conservatism, both internal and external. In his opinion, Moscow has always sought to produce an alternative to the Western liberal consensus. Matthew Crosston also turns to the ideational origins of Russia's policy, but in a somewhat unusual way. He views Putin in the context of the populist wave that has swept across the world lately, noting similarities between the Russian version of "power populism" and Western models, as well as their differences. He believes that the rise of populism per se is a reaction of society to the deep crisis of classical ideologies. The same issue is addressed by our Roundtable panelists-leading Russian journalists and political scientists-whom we invited to discuss the phenomenon of populism and its post-Soviet forms.

The current issue of the journal features an unusual section titled Glossary designed to provide an insight into the conceptual foundations of politics. Trapped in the midst of turbulent events both in the world and in Russia, we decided to draw up a list of notions that are important for Russian foreign policy, and asked our leading specialists in political and social issues to explain them. 


\section{RUSSIA IN GLOBAL AFFAIRS}
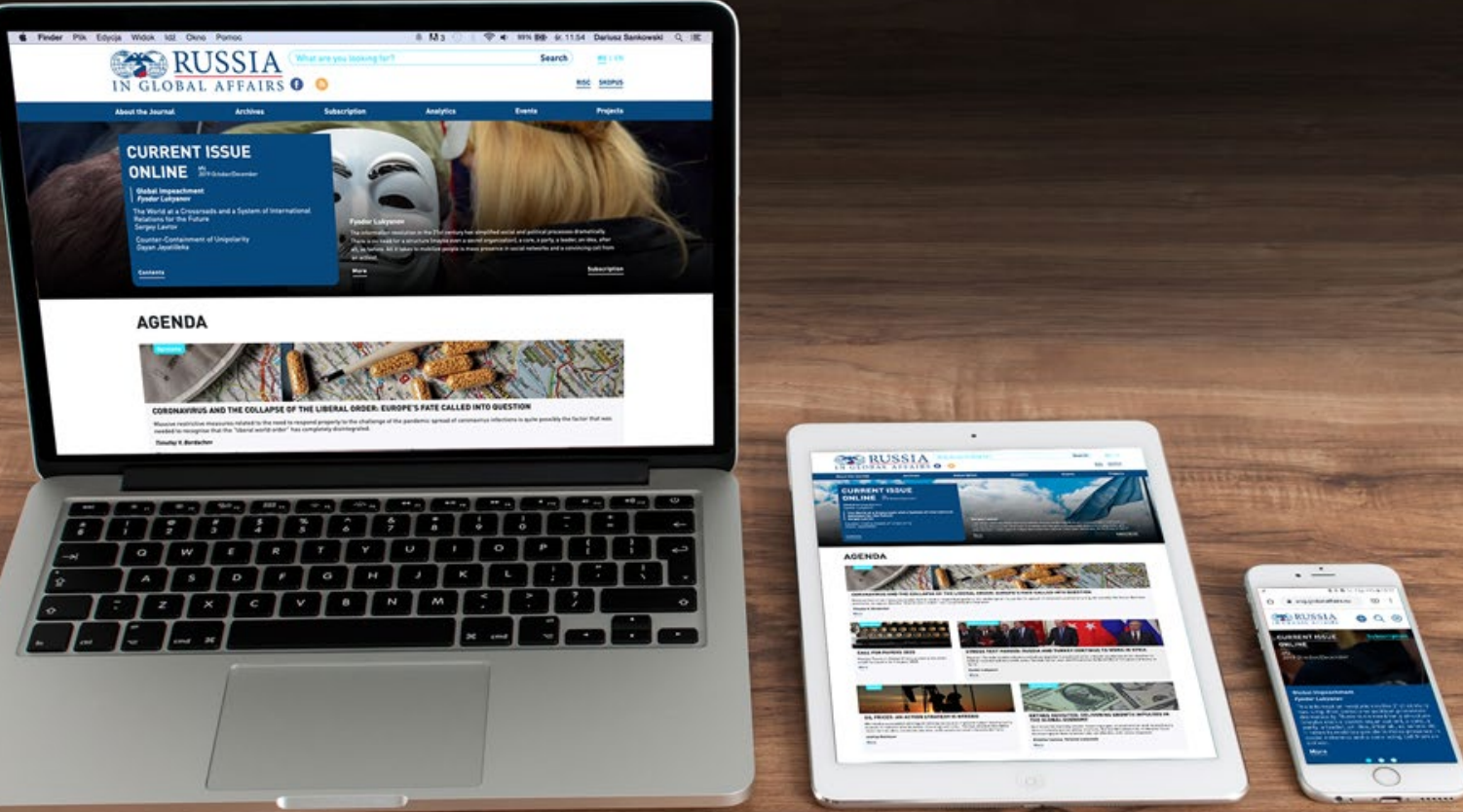

eng.globalaffairs.ru

is now available on all devices.

Stay with us! 
We hope that those who are professionally engaged in Russian politics will find this idea useful.

The enduring principles of Russia's foreign policy philosophy are discussed in an interview with renowned historian Dominic Lieven.

Finally, there is a more practical section. Dmitry Trenin ruminates about the significance of the U.S. elections for U.S.-Russia relations. In short, there is nothing good, but nothing terrible either. It is hard to make things worse than they already are, but nor can they get any better. Elena Ponomareva addresses the issue of Serbia and Russian-Serbian relations. These are very long-standing and very close ties, filled with historical and ideological allusions more than most other interstate contacts. Natalia Pomozova takes a look at both sides of the border, east and west, focusing on Europe's perception of China's "One Belt, One Road" initiative. For Russia, this is an important part of the surrounding world not only because there are neighbors on both sides, but because the formation of a large Eurasian community is both a practical perspective and an ideological construct, essential at the current stage.

So, there's a lot of food for thought. Particularly, while the quarantine lasts we should contemplate ideas and conceptions, in order to come out of it rejuvenated and eager to start building a new brave world. 